\title{
A Preliminary Analysis of Islamic Real Estate Investment Trust (I-REIT) Volatility as a Potential Waqf Development
}

\author{
Azhan Rashid Senawi* \\ Department of Management and Humanities, Universiti Teknologi PETRONAS, 32610 Seri Iskandar, Perak, Malaysia \\ *Corresponding author: azhan_g02545@utp.edu.my
}

Article history: Received: 3 May 2018 Received in revised form: 24 July 2018 Accepted: 20 August 2018 Published online: 28 November 2018

\begin{abstract}
The development of waqf institutions is a significant attribution to ensure a sustainable and progressive prosperity to the Muslim socio-economic. The aspiration of the waqf development is to preserve the benefits of the beneficiaries and to all the human kind. However, the issues of the fund shortage are one of the tough issues that need to be solved. I-REIT (Islamic Real Estate Investment Trust) is one of a suggestion of diversification as an alternative solution to the aspect of fund constraint. Therefore, this paper attempts to examine the level of I-REIT volatility in comparison to typical REIT as a preliminary experiment. By using a conventional standard deviation or variance analysis of selected I-REIT and REIT counter, a preliminary result shows that I-REIT has a lower volatility impact than the REIT. This less-impact I-REIT to the market exploitation justifies that the Islamic capital market instruments of Islamic real estate investment trust (I-REIT) is an alternative potential waqf mechanism in developing and advancing waqf property in Malaysia. Thus, this study proposes the initiation of the alternative waqf of I-REIT in enhancing the dynamism of waqf practice in Malaysia.
\end{abstract}

Keywords: Waqf; I-REIT; Volatility; Malaysia

Abstrak
Perkembangan institusi waqaf adalah penting bagi memastikan kesejahteraan yang mampan dan progresif kepada sosio-ekonomi Islam. Aspirasi
perkembangan waqaf adalah untuk memelihara manfaat para penerima manfaat dan seluruh manusia secara umumnya. Walau bagaimanapun, masalah
kekurangan dana adalah salah satu isu yang sukar dan perlu diselesaikan. I-REIT (Amanah Pelaburan Hartanah Islam) adalah cadangan penyelesaian alternatif
kepada aspek kekangan dana ini. Oleh itu, kertas kerja ini cuba untuk menilai tahap ketidaktentuan kemeruapan I-REIT berbanding REIT konvensional sebagai
satu kajian rintis. Dengan menggunakan sisihan piawai konvensional atau analisis varians ke atas kaunter I-REIT dan REIT terpilih, keputusan awal
menunjukkan bahawa I-REIT mempunyai kesan turun naik yang lebih rendah berbanding REIT. Impak rendah I-REIT memberi justifikasi bahawa instrumen
pasaran modal ini adalah instrumen alternatif yang berpotensi dalam membangunkan pelaburan hartanah Islam (I-REIT) dan salah satu cara memajukan harta
waqaf di Malaysia. Oleh itu, kajian ini mencadangkan inisiatif waqaf alternatif I-REIT dalam meningkatkan dinamika waqaf di Malaysia sebagai satu praktik.

Kata kunci: Waqaf; I-REIT; Pemeruapan; Malaysia

(C) 2018 Penerbit UTM Press. All rights reserved

\subsection{INTRODUCTION}

For decades, the area of Islamic finance has created a positive attention of many researchers. However, discussion on waqf development has less been entertained in the Islamic financial environment. Malaysia, as a becoming developed country has led the world societies to be the Islamic financial role initiator in mobilizing a dynamic international financial landscape (Bank Negara Malaysia, 2010). Nonetheless, in terms of waqf development, there is a need to be rejuvenated. This illustrates the imbalance development between the waqf institutions with the other Islamic financial instruments. However lately, it has been seen an improvement. There is an effort for waqf to be reviewed in terms of its perspective of development, thereby a new-window initiative has been adapted to fit the current situation such as from NGOs, corporate bodies and government agencies (Ihsan \& Adnan, 2009; Nahar, \& Yaacob, 2011; Syahnaz, Aznan, \& Ahmad, 2014).

In line with the rapid development of the Islamic financial system, the waqf assets should be dynamically developed to suit the rapid growth of Islamic financial system. Therefore, one of the approaches to develop the waqf assets in a creative and innovative way that based on its current reality is by the application of Islamic real estate investment trust instruments (I-REIT) which is also an Islamic capital market instrument (Syahnaz et al., 2014).

I-REIT applies as similar as a conventional REIT as both are the investment tools by pooling money from investors and utilize it in the form of buying, managing and selling the real estate (Lembaga Hasil Dalam Negeri Malaysia, 2012). The only difference lies in its legal requirements, which includes the sharīah board of committee or advisor in a certain implementation of professional functions (Mahjom, Mohd. Hussin, Mohamad, \& Yusuf, 2013). I-REIT returns are generated from the rent revenue and capital markup issued from the asset property holders in the period of the investment. Those who gain the unit will receive a return in the form of income distribution and capital gains (Securities Commission Malaysia, 2005). 
I-REITs are one of the investment instruments which at least 50 percent of the total assets are invested in real estate, either through a direct ownership or a special purpose company (Securities Commission Malaysia, 2005). In other words, I-REITs are only allowed to invest in real estate, special purpose company (SPC), property-related assets, non-real estate assets and cash, deposits and money market instruments.

From these exclusive investments activities, there could be a measurement regarding the robustness of its volatility (I-REIT) compared to the REIT in the capital market. This is imperative for the evaluation purpose of the investor level of assurance. Therefore, this study has put a significant question in guiding the analysis. The questions are as follows:

1. Does I-REIT has less volatility than REIT?

2. Does I-REIT more stable than REIT?

The discussion has been organized as follows. The following part will be the literature review. Then, the analysis will take part onwards including the model, the estimation technique, and the result and discussion. The final part will conclude and resume the analysis in the study.

\subsection{LITERATURE REVIEW}

The study regarding the Real Estate Investment Trust (REIT) performance on capital market development has an extensive exploration, particularly in the United States. However, there is limited studies in Malaysia especially in the Islamic property investment aspect. This is probably due to its new-introduction investment instrument created in the Islamic Capital Market.

Hamzah, Rozali and Tahir (2010) who review the REITs in Malaysia by using the Sharpe Index, Treynor Index, and Jensen Index has proven a stable performance of REIT during the financial crisis in 1997 to 1998 . However, it is began to disrupt in the pasca-crisis period of 1998 to 2005. It shows the average systematic risk for REIT is higher than the current and during market portfolio crisis. Meanwhile, Lian and Kim (1986) asserts that the systematic risks inherent in listed property trust has increased after the speculative period of January 1994 to April 1995. It exposes that the speculative effect in the period of 1995 is huge. But, it returns to mild during the post-crisis periods.

An analysis on the returns of REITs in Malaysia in the current economic conditions posits that REITs dividend contributed significantly to the total returns of REITs (Hwa \& Abdul Rahman, 2007). Whereas, Brooks and Tsolacos (1999) who utilizing the VAR model on REITs and its relationship to macroeconomic factors reveal that inflation and interest rates have a significant influence on REITs.

Furthermore, there is also a case study of four property trusts registered performance, namely Maybank Property Trust Fund One, Amanah Treasury PNB, First Malaysia Property Trust and Arab Malaysian First Property Trust. The measurement of the standard deviation of the proxy reveals that the variance of the Maybank Property Trust Fund One, Amanah Treasury PNB, and First Malaysia Property Trust is higher than market risk (Newell, Yue, Kwongwing, \& Siukei, 2010).

Another analysis on the performance of Malaysian listed property companies that based on the conditions of economic performance by Abdullah and Wan Zahari (2008) disclose that the listed property companies significantly out-performed the market portfolio. From the aspect of risk-adjusted performance and portfolio diversification between the I-REITs and REIT in Malaysia, indicate that the I-REITs has a lower risk level features than REITs (Newell \& Osmadi, 2010). Moreover, a study on the aspect of transparency, disclosure, share liquidity, depth of management and corporate democracy affirms that the Malaysian REITs have satisfied all the component specification (Ong, Teh, \& Chong, 2011).

Therefore, due to the gap from the above discussions, the study draws a hypothesis such as follows;

$H_{l}: \quad$ I-REIT has a lower volatility than REIT.

$\mathrm{H}_{2}$ : $\quad$ I-REIT is more stable than REIT

Accordingly, a further investigation could bring a clearer justification regarding the I-REITs as a knowledge enhancement for a starting proposal of the waqf potential development in Malaysia.

\subsection{ESTIMATION TECHNIQUE}

This study uses a simple technique to measure the volatility between the I-REITs and the REIT. The variance measurement will be used in order to achieve the aim of the study. Therefore, the general formula will be specified as:

$$
\left.\sigma^{2}=\sum(X-\mu)^{2}\right) / N
$$

Where, $\sigma 2$ denotes a variance, $\mathrm{X}$ denotes I-REIT/REIT price, $\mu$ denotes mean and $\mathrm{N}$ represents the total estimation. From this estimation approach, the hypothesis will be measured.

\subsection{METHODOLOGY}

This is a quantitative research design. It employs a monthly data of the selected I-REITs and REITs companies of their closing prices since listed on the Bursa Malaysia. The participated companies are Al Salam REIT, Al 'Aqar Healthcare REIT and Axis REIT that are representing I-REIT. While, the Yeoh Tiong Lay (YTL) REIT, United Ostomy Association (UOA) REIT and Ipoh Garden Berhad (IGB) REIT are representing the conventional REIT. Nonetheless, due to non-uniform data from the companies, therefore the study will justify based on only the available data.

\subsection{RESULTS AND DISCUSSION}


Stock market including the REIT and I-REIT volatility is important because an exact expectations in its volatility enable investors to make efficient decisions (Hussin, 2003). By assessing the economic determinant involved, it could be predicted that a high volatility rarely occurs during the economic slowdown and financial crisis.

Table 1 Variance analysis of I-REIT and REIT counters

\begin{tabular}{lccccc}
\hline \multirow{2}{*}{ Counters } & \multicolumn{5}{c}{ Year } \\
\cline { 2 - 5 } & $\mathbf{2 0 1 2}$ & $\mathbf{2 0 1 3}$ & $\mathbf{2 0 1 4}$ & $\mathbf{2 0 1 5}$ & $\mathbf{2 0 1 6}$ \\
\hline Al ' 'Aqar & 0.006687 & $0.000384^{*}$ & $0.000644^{*}$ & 0.001824 & 0.003487 \\
Al Salam & - & - & - & $0.000866^{*}$ & $0.001340^{*}$ \\
AXIS & - & - & - & 0.003050 & 0.005135 \\
YTL & 0.006090 & 0.001696 & 0.002590 & 0.001202 & 0.002675 \\
UOA & 0.001442 & 0.002881 & 0.000935 & 0.001590 & 0.002769 \\
IGB & $0.000430^{*}$ & 0.006669 & 0.004725 & 0.001815 & 0.004706 \\
\hline \multicolumn{2}{c}{ Notes: * indicates a low variance or standard variation in that particular year. (-) indicates the data not available. An Italic font indicates the I-REIT counters. }
\end{tabular}

Accordingly, the result of the variance analysis on Table 1 explains that in most of the counters assessed from 2012 to 2016 , the IREIT counter has a lower variance than the REIT counter. On 2013, Al 'Aqar shows the lowest among others, followed by 2014,2015 and 2016 where the I-REIT counter is the lowest compared to other REIT counters. Only on 2012, the IGB which represents the REIT counter is at around 0.0004 compared to the I-REIT counter. This indicates the REIT counter is more volatile than the I-REIT. In other words, REIT is fragile to the economic downturn, while the I-REIT is stable.

Therefore, from this analysis, it suggests that the I-REIT is very compatible to be a potential waqf alternative of development due to its low volatility among other REIT counter. It also has a potential to be one of the long term investment instruments that can attract foreign and domestic investors as being suggested by Mahjom et al. (2013) and Mohd Yahya, Yusni, Fidlizan, Azila \& Fatimah (2014).

This variance analysis of I-REIT posits that they have vast potential and is a completely unexplored market. With a more comprehensive legislative framework and a more dynamic market environment in the future, I-REIT is expected to benefit Malaysia to attract more foreign investors from Asia and the Middle East to set up I-REIT in the country. This could increase the size of Syariah compliant real estate investment funds (Syahnaz et al., 2014).

\subsection{CONCLUSION}

This study examines the volatility comparison by using a conventional analysis between the I-REIT and the REIT counters in Malaysia. The preliminary results of the analysis suggests that there is a significant finding of the I-REIT and it confirms the hypothesis of the previous research regarding the low volatility effect of the I-REIT counters compared to the REIT counter. It also indicates that the I-REIT is more stable than the REIT.

Therefore, from this preliminary study, we suggest the authority of waqf institutions or the government to take a proactive action in boosting the waqf promotion for the purpose of the nation development in the future. This finding also keen to suggest that this analysis (waqf volatility analysis) could be extended to the Autoregressive Conditional Heteroskedasticity (ARCH) and Generalised Autoregressive Conditional Heteroskedasticity $(\mathrm{GARCH})$ analysis due to the validity and efficiency of its finding.

\section{References}

Abdullah, N. A., \& Wan Zahari, W. M. (2008). Performance of Property Listed Companies in Malaysia: 1996 - 2007. Unpublished Master Thesis, Universiti Utara Malaysia, Malaysia, 1-41.

Bank Negara Malaysia. (2010). Shariah Resolution in Islamic Finance. Bank Negara Malaysia, 215.

Brooks, C., \& Tsolacos, S. S. (1999). The Impact of Economic and Financial Factors on UK Property Performance. Journal of Property Research, 16(2), 139-152. http://doi.org/10.1080/095999199368193

Hamzah, A. H., Rozali, M. B., \& Tahir, I. M. (2010). Empirical Investigation on the Performance of the Malaysian Real Estate Investment Trusts in Pre-Crisis, During Crisis and Post-Crisis Period. International Journal of Economics and Finance, 2(2), 62-69. http://doi.org/10.5539/ijef.v2n2P62

Hwa, T. K., \& Abdul Rahman, M. Y. (2007). Stability of Dividends and FFOs : The Case of REITs in Malaysia. In 13th Pacific-Rim Real Estate Society Annual Conference, Perth, Western Australia.

Ihsan, H., \& Adnan, M. (2009). Waqf Accounting and The Construction of Accountability. Humanomics, 27, $252-269$.

Lembaga Hasil Dalam Negeri Malaysia. (2012). Garis Panduan Amanah Pelaburan Harta Tanah / Tabung Amanah Harta.

Lian, K. K., \& Kim, K. L. (1986). Performance of Property Trusts in the Kuala Lumpur Stock Exchange. Kuala Lumpur.

Mahjom, N., Mohd. Hussin, M. Y., Mohamad, F., \& Yusuf, Y. A. (2013). Potensi Amanah Pelaburan Hartanah Islam (I-REITs) Dalam Penjagaan Kesihatan. In Prosiding Perkem VIII (pp. 516-523).

Mohd Hussin,M.Y. (2003). Hubungan Kemeruapan Antara Pembolehubah Makroekonomi, Pasaran Saham Islam dan Konvensional di Malaysia. Jurnal Syariah, 11(2), 135-159. Retrieved from http://myais.fsktm.um.edu.my/7516/

Mohd Hussin,M.Y, Yusni A.Y, Fidlizan M., Azila A.R., Fatimah S.A.H. (2014). Potentials of Islamic Real Estate Investment Trusts ( I-REITs ) in Advancing Oil Palm Industry in Malaysia. Malaysian Journal of Society and Space, 10(3), 101-112.

Newell, G., \& Osmadi, A. (2010). Assessing the Importance of Factors Influencing the Future Development of Reits in Malaysia. Pacific Rim Property Research Journal, 16(3), 358-374. http://doi.org/10.1080/14445921.2010.11104309

Newell, G., Yue, W., Kwongwing, C., \& Siukei, W. (2010). The Development and Performance of Reits in Hong Kong. Pacific Rim Property Research Journal, 16(2), 190-206. http://doi.org/10.1080/14445921.2010.11104301

Ong, T. S., Teh, B. H., \& Chong, M. P. (2011). A Study on The Performance of Malaysia Real Estate Investment Trusts From $2005-2010$ by Using Net Asset Value Approach. International Journal of Economic and Research, 2(1), 1-15.

Securities Commission Malaysia. (2005). Guidelines for Islamic Real Estate Investment Trusts. Retrieved September 19, 2017, from Securities Commission Malaysia 
Suhaimi N., H., Yaacob, H., Nahar, H. S., \& Yaacob, H. (2011). Accountability in the Sacred Context: The Case of Management, Accounting and Reporting of a Malaysian Cash Awqaf Institution. Journal of Islamic Accounting and Business Research, 2(2), 87-113. http://doi.org/10.1108/17590811111170520

Syahnaz S., Aznan H., \& Ahmad A.S. (2014). Potensi Pembangunan Harta Wakaf Menerusi Mekanisme Amanah Pelaburan Hartanah Islam (Islamic Real Estate Investment/ I-REIT) di Malaysia. Jurnal Muamalat, 7, 1-28.

Appendix

$\mathrm{Al}$ 'Aqar REIT

\begin{tabular}{|c|c|c|c|c|c|c|c|c|c|}
\hline 2012 & & 2013 & & 2014 & & 2015 & & 2016 & \\
\hline Mean & 1.341667 & Mean & 1.3375 & Mean & 1.394167 & Mean & 1.353333 & Mean & 1.561667 \\
\hline Standard I & 0.023608 & Standard I & 0.005658 & Standard I & 0.00733 & Standard E & 0.01233 & Standard E & 0.017049 \\
\hline Median & 1.355 & Median & 1.33 & Median & 1.4 & Median & 1.33 & Median & 1.555 \\
\hline Mode & 1.31 & Mode & 1.33 & Mode & 1.4 & Mode & 1.32 & Mode & 1.56 \\
\hline Standard I & 0.081779 & Standard I & 0.019598 & Standard I & 0.025391 & Standard [ & 0.042711 & Standard [ & 0.059058 \\
\hline Sample V: & 0.006688 & Sample V: & 0.000384 & Sample Vi & 0.000645 & Sample Vi & 0.001824 & Sample Vi & 0.003488 \\
\hline Kurtosis & -0.48295 & Kurtosis & 4.767835 & Kurtosis & 2.986564 & Kurtosis & -1.75535 & Kurtosis & 1.922747 \\
\hline Skewness & -0.47749 & Skewness & 1.809727 & Skewness & 0.076547 & Skewness & 0.412879 & Skewness & 1.2372 \\
\hline Range & 0.25 & Range & 0.08 & Range & 0.11 & Range & 0.12 & Range & 0.22 \\
\hline Minimum & 1.2 & Minimum & 1.31 & Minimum & 1.34 & Minimum & 1.3 & Minimum & 1.48 \\
\hline Maximum & 1.45 & Maximum & 1.39 & Maximum & 1.45 & Maximum & 1.42 & Maximum & 1.7 \\
\hline Sum & 16.1 & Sum & 16.05 & Sum & 16.73 & Sum & 16.24 & Sum & 18.74 \\
\hline Count & 12 & Count & 12 & Count & 12 & Count & 12 & Count & 12 \\
\hline
\end{tabular}

Al Salam REIT

\begin{tabular}{|l|r|r|r|}
\hline \multicolumn{1}{|c|}{2015} & & \multicolumn{1}{|c|}{2016} \\
\hline & & & \\
\hline Mean & 0.96 & Mean & 1.025 \\
\hline Standard Error & 0.01472 & Standard E & 0.010571 \\
\hline Median & 0.955 & Median & 1.04 \\
\hline Mode & \#N/A & Mode & 1.04 \\
\hline Standard Deviatic & 0.029439 & Standard I & 0.036618 \\
\hline Sample Variance & 0.000867 & Sample V & 0.001341 \\
\hline Kurtosis & 1.5 & Kurtosis & -0.54043 \\
\hline Skewness & 0.940661 & Skewness & -0.67152 \\
\hline Range & 0.07 & Range & 0.115 \\
\hline Minimum & 0.93 & Minimum & 0.955 \\
\hline Maximum & 1 & Maximum & 1.07 \\
\hline Sum & 3.84 & Sum & 12.3 \\
\hline Count & 4 & Count & 12 \\
\hline
\end{tabular}

Axis REIT

\begin{tabular}{|l|r|r|r|}
\hline \multicolumn{1}{|c|}{2015} & & \\
\hline & & & \\
\hline Mean & 1.63 & Mean & 1.685833 \\
\hline Standard Error & 0.024698178 & Standard Error & 0.020687 \\
\hline Median & 1.64 & Median & 1.69 \\
\hline Mode & \#N/A & Mode & 1.61 \\
\hline Standard Deviation & 0.055226805 & Standard Deviation & 0.071663 \\
\hline Sample Variance & 0.00305 & Sample Variance & 0.005136 \\
\hline Kurtosis & 0.774522978 & Kurtosis & -0.17686 \\
\hline Skewness & -0.415573916 & Skewness & -0.297 \\
\hline Range & 0.15 & Range & 0.25 \\
\hline Minimum & 1.55 & Minimum & 1.55 \\
\hline Maximum & 1.7 & Maximum & 1.8 \\
\hline Sum & 8.15 & Sum & 20.23 \\
\hline Count & 5 & Count \\
\hline
\end{tabular}




\begin{tabular}{|c|c|c|c|c|c|c|c|c|c|}
\hline 2012 & & 2013 & & 2014 & & 2015 & & 2016 & \\
\hline Mean & 1.01 & Mean & 1.053333 & Mean & 0.960833 & Mean & 1.0425 & Mean & 1.1025 \\
\hline Standard $\mathrm{E}$ & 0.022529 & Standard I & 0.011892 & Standard I & 0.014692 & Standard I & 0.004106 & Standard E & 0.01493 \\
\hline Median & 1.025 & Median & 1.045 & Median & 0.955 & Median & 1.04 & Median & 1.08 \\
\hline Mode & 1.11 & Mode & 1.01 & Mode & 1 & Mode & 1.03 & Mode & 1.07 \\
\hline Standard I & 0.078044 & Standard I & 0.041194 & Standard I & 0.050894 & Standard I & 0.014222 & Standard [ & 0.05172 \\
\hline Sample Va & 0.006091 & Sample Vi & 0.001697 & Sample Vi & 0.00259 & Sample Vi & 0.000202 & Sample Vi & 0.002675 \\
\hline Kurtosis & -1.72452 & Kurtosis & -0.84015 & Kurtosis & -1.77933 & Kurtosis & -0.62548 & Kurtosis & 0.817172 \\
\hline Skewness & -0.08262 & Skewness & 0.575669 & Skewness & 0.150421 & Skewness & 0.839008 & Skewness & 1.171813 \\
\hline Range & 0.21 & Range & 0.12 & Range & 0.13 & Range & 0.04 & Range & 0.17 \\
\hline Minimum & 0.9 & Minimum & 1.01 & Minimum & 0.9 & Minimum & 1.03 & Minimum & 1.05 \\
\hline Maximum & 1.11 & Maximum & 1.13 & Maximum & 1.03 & Maximum & 1.07 & Maximum & 1.22 \\
\hline Sum & 12.12 & Sum & 12.64 & Sum & 11.53 & Sum & 12.51 & Sum & 13.23 \\
\hline Count & 12 & Count & 12 & Count & 12 & Count & 12 & Count & 12 \\
\hline
\end{tabular}

\section{UOA REIT}

\begin{tabular}{|c|c|c|c|c|c|c|c|c|c|}
\hline 2012 & & 2013 & & 2014 & & 2015 & & 2016 & \\
\hline Mean & 1.386667 & Mean & 1.444167 & Mean & 1.414167 & Mean & 1.585 & Mean & 1.676667 \\
\hline Standard I & 0.010964 & Standard I & 0.015495 & Standard I & 0.00883 & Standard I & 0.011514 & Standard E & 0.015192 \\
\hline Median & 1.37 & Median & 1.45 & Median & 1.41 & Median & 1.59 & Median & 1.665 \\
\hline Mode & 1.37 & Mode & 1.45 & Mode & 1.45 & Mode & 1.6 & Mode & 1.64 \\
\hline Standard I & 0.037979 & Standard I & 0.053676 & Standard I & 0.030588 & Standard I & 0.039886 & Standard I & 0.052628 \\
\hline Sample V: & 0.001442 & Sample V: & 0.002881 & Sample Vi & 0.000936 & Sample Vi & 0.001591 & Sample Vi & 0.00277 \\
\hline Kurtosis & -1.05168 & Kurtosis & -0.98189 & Kurtosis & -0.75178 & Kurtosis & 0.672631 & Kurtosis & -1.49851 \\
\hline Skewness & 0.368622 & Skewness & 0.028208 & Skewness & -0.08582 & Skewness & -0.62922 & Skewness & 0.301693 \\
\hline Range & 0.12 & Range & 0.17 & Range & 0.1 & Range & 0.14 & Range & 0.15 \\
\hline Minimum & 1.33 & Minimum & 1.36 & Minimum & 1.36 & Minimum & 1.5 & Minimum & 1.61 \\
\hline Maximum & 1.45 & Maximum & 1.53 & Maximum & 1.46 & Maximum & 1.64 & Maximum & 1.76 \\
\hline Sum & 16.64 & Sum & 17.33 & Sum & 16.97 & Sum & 19.02 & Sum & 20.12 \\
\hline Count & 12 & Count & 12 & Count & 12 & Count & 12 & Count & 12 \\
\hline
\end{tabular}

\section{IGB REIT}

\begin{tabular}{|c|c|c|c|c|c|c|c|c|c|}
\hline 2012 & & 2013 & & 2014 & & 2015 & & 2016 & \\
\hline Mean & 1.344 & Mean & 1.278333 & Mean & 1.253636 & Mean & 1.338333 & Mean & 1.608333 \\
\hline Standard I & 0.009274 & Standard I & 0.023576 & Standard I & 0.020726 & Standard I & 0.012299 & Standard E & 0.019803 \\
\hline Median & 1.34 & Median & 1.25 & Median & 1.27 & Median & 1.345 & Median & 1.61 \\
\hline Mode & $\# N / A$ & Mode & 1.36 & Mode & 1.2 & Mode & 1.35 & Mode & 1.61 \\
\hline Standard I & 0.020736 & Standard I & 0.081668 & Standard I & 0.068742 & Standard I & 0.042605 & Standard I & 0.068601 \\
\hline Sample Vi & 0.00043 & Sample Vi & 0.00667 & Sample V: & 0.004725 & Sample V: & 0.001815 & Sample Vi & 0.004706 \\
\hline Kurtosis & -1.96322 & Kurtosis & -1.68728 & Kurtosis & -1.26004 & Kurtosis & 2.076897 & Kurtosis & 0.405494 \\
\hline Skewness & 0.235514 & Skewness & 0.368686 & Skewness & -0.47485 & Skewness & 0.984477 & Skewness & 0.382816 \\
\hline Range & 0.05 & Range & 0.22 & Range & 0.19 & Range & 0.16 & Range & 0.24 \\
\hline Minimum & 1.32 & Minimum & 1.19 & Minimum & 1.14 & Minimum & 1.28 & Minimum & 1.51 \\
\hline Maximum & 1.37 & Maximum & 1.41 & Maximum & 1.33 & Maximum & 1.44 & Maximum & 1.75 \\
\hline Sum & 6.72 & Sum & 15.34 & Sum & 13.79 & Sum & 16.06 & Sum & 19.3 \\
\hline Count & 5 & Count & 12 & Count & 11 & Count & 12 & Count & 12 \\
\hline
\end{tabular}

